\title{
FORMATION OF TERPENES IN GRAPES AND WINES
}

\section{TWORZENIE SIĘ TERPENÓW W WINOGRONACH I WINACH}

Department of Fermentation Technology and Technical Microbiology, University of Agriculture, Kraków, Poland

\begin{abstract}
Streszczenie. Jakościowy i ilościowy skład związków lotnych w napojach alkoholowych zależy głównie od jakości użytego surowca i rodzaju zastosowanych drożdży oraz od warunków fermentacji, leżakowania i przechowywania produktów końcowych. Związki aromatu mogą kształtować przyjemny zapach i smak lub pogarszać właściwości organoleptyczne wina. Związki lotne powstają w procesach biologicznych, enzymatycznych i chemicznych, głównie w trakcie procesu fermentacji etanolu. Estry, aldehydy, wyższe alkohole, kwasy organiczne i dotychczas słabo przebadane terpeny są najważniejszymi związkami zapachowymi w napojach alkoholowych. Niektóre terpeny wykryto jedynie w soku winogronowym; w trakcie fermentacji ilość tych związków zmniejszyła się do niewykrywalnego poziomu. Do terpenów najczęściej występujących w winach należą: nerol (cytrusowy aromat), citronellol (różany aromat), geraniol (zapach róży $z$ aromatem geranium), limonen (pomarańczowy, cytrusowy aromat), linalool (kojarzony z kwiatowym, lawendowym aromatem), citral (kojarzony z zapachem cytrusów) i $\beta$-ionone (o kwiatowym aromacie z malinową nutą).
\end{abstract}

Key words: terpenes, volatile compounds, wine, grapes, aroma.

Słowa kluczowe: terpeny, związki lotne, wino, winogrona, aromat.

\section{INTRODUCTION}

Volatile organic compounds in wine are responsible for the taste and aroma of the beverage. "Volatile" describes the compounds that can be detected in low amounts in room temperature without any chemical combination process (Clarke and Bakker 2006). Most of the components present in wine are in very small amounts, that can be expressed in ppm, ppb or even ppt. However every compound must be present in the quantity above the threshold value in order to be noticeable. In the literature sensory threshold values in water can be found most commonly, there is lack of information about these values in wines when ethanol is present. Volatile compounds of wines can be divided in three groups depending on their source, such as primary aromas, that persist from grapes; secondary aromas, which were produced by yeasts during fermentation process and tertiary aromas, the ones that were formed during the storage in the wooden barrels or glass bottles (Clarke and Bakker 2006).

Corresponding author - Adres do korespondencji: Magdalena Kostrz, Department of Fermentation Technology and Technical Microbiology, University of Agriculture, Balicka 122, 30-149 Kraków, Poland, e-mail: magdalena.kostrz@urk.edu.pl 
The quality of beverages is closely dependent on quality of the raw material, type of applied yeasts and fermentation processes. Aroma of overripe fruits quickly fades and unripe fruits contain less sugars and are not suitable for high-quality wines production (Pischl 2010). Some substances such as terpenes, are present in low concentrations but significantly affect the sensory features of alcoholic beverages. They have a pleasant, fruity aroma of: cloves (eugenol), roses (geraniol), citrus (limonene), rosewood (linalool) or apricots, walnuts and oranges (myrcene) (Dixon and Hewett 2000; Fraternale at al. 2011; El Hadi at al. 2013).

The aim of this work is to present terpenes forming in grapes and wines.

\section{TERPENES}

Terpenes are bioactive compounds produced in plant cells defined as non-nutritive constituents of food, which usually occur in very small quantities (Hayashi 1978; Grassmann 2005). Many terpenes are volatile and have pleasant smell, though the odour thresholds of terpenoids (derivatives of terpenes) vary greatly (Belitz et al. 2004). Terpenes and terpenoids are widely distributed in nature, occur in small quantities in grapes and persist through vinification (Clarke and Bakker 2006). Terpenes are are built up from isoprene; therefore, they are also called isoprenoids. They are divided on the basis of their C-skeleton (Graßmann 2005) into monoterpenes, sesquiterpenes, diterpenes, triterpenes, etc. For example, monoterpenes (10 carbons) are synthesized from geranyl diphosphate (GPP), while sesquiterpenes (15 carbons) are produced from farnesyl diphosphate (FPP) and diterpenes (20 carbons) from geranylgeranyl diphosphate (GGPP). In red and white wines the most commonly monoterpenes and sesquiterpenesare found (Lund and Bohlmann 2006; Martin et. al. 2009; Gil et al. 2012; Henry et al. 2015). Figure 1 presents the structures of the most important terpenes for wine aroma.

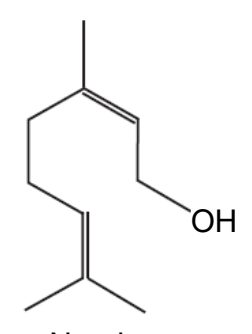

Nerol

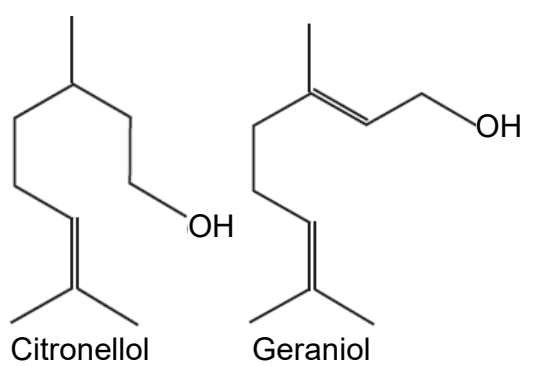

Citronellol
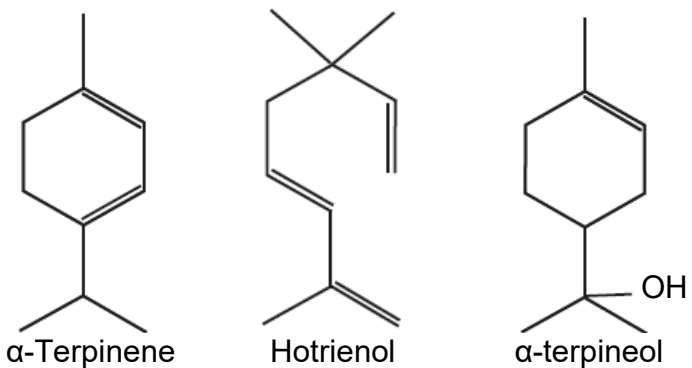

Fig. 1. The structure of the most common wine terpenoids

Ryc. 1. Struktury terpenów najczęściej występujących w winach

Terpenes can be biosynthesized only by higher plants, algae, fungi and some yeasts and are initiated by condensation of 3 molecules of acetyl-CoA. Further reactions lead to formation of geranyl pyrophosphate (GPP) which is a precursor for monoterpenes (Fig. 2). Most compounds derived from terpene biosynthesis in wine grapes are actually terpenoids, which are terpenes or terpene alcohols (terpene synthases can produce alkenes by deprotonation or alcohols by water capture) that have undergone chemical transformation(s), typically oxidation (sometimes promoted by enzymes, sometimes not). Among the others there are 
two important plant species for beverages production that can produce monoterpenes Vitisvinifera (grapes) and Humuluslupulus (hops) - King and Dickinson (2000). Genomes of the various Vitisvinifera varieties have been mapped, with an emphasis on identifying terpene synthase/cyclase coding regions. Yeast species that can produce terpenes are Kluyveromyceslactis, Torulasporadelbrueckii (Saccharomyces fermentanti) and Ambrosiozymamonospora (Drawert and Barton 1978; Fagan et al. 1981; Klingenberg and Sprecher 1985). Native strains of Saccharomyces cerevisiae are able to form only trace amounts of terpenes comparing to the amounts present in wines. Recent studies was reportedby Carrau et al. (2005) on the native wine strains isolated in Uruguay has shown that several of them are capable to synthesize the significant amounts of these volatiles. Fermentation conditions can also affect the terpenes synthesis. High nitrogen content about $400 \mathrm{mg} /$ Lstimulates monoterpenes biosynthesis, but does not affect on sesquiterpenes synthesis. Farther surveys on the yeasts metabolism showed that there is an alternative pathway for sesquiterpenes synthesis, independent from sterol, that involves the conversion of leucine andmevalonic acid (Carrau et al. 2005). It is initiated by acetyl-CoA or by the reaction of D-glycerol-3-phosphate and pyruvate. During synthesis three molecules of acetyl-CoA are bounded together to form 3-hydroxy-3-methylglutaryl-CoA.

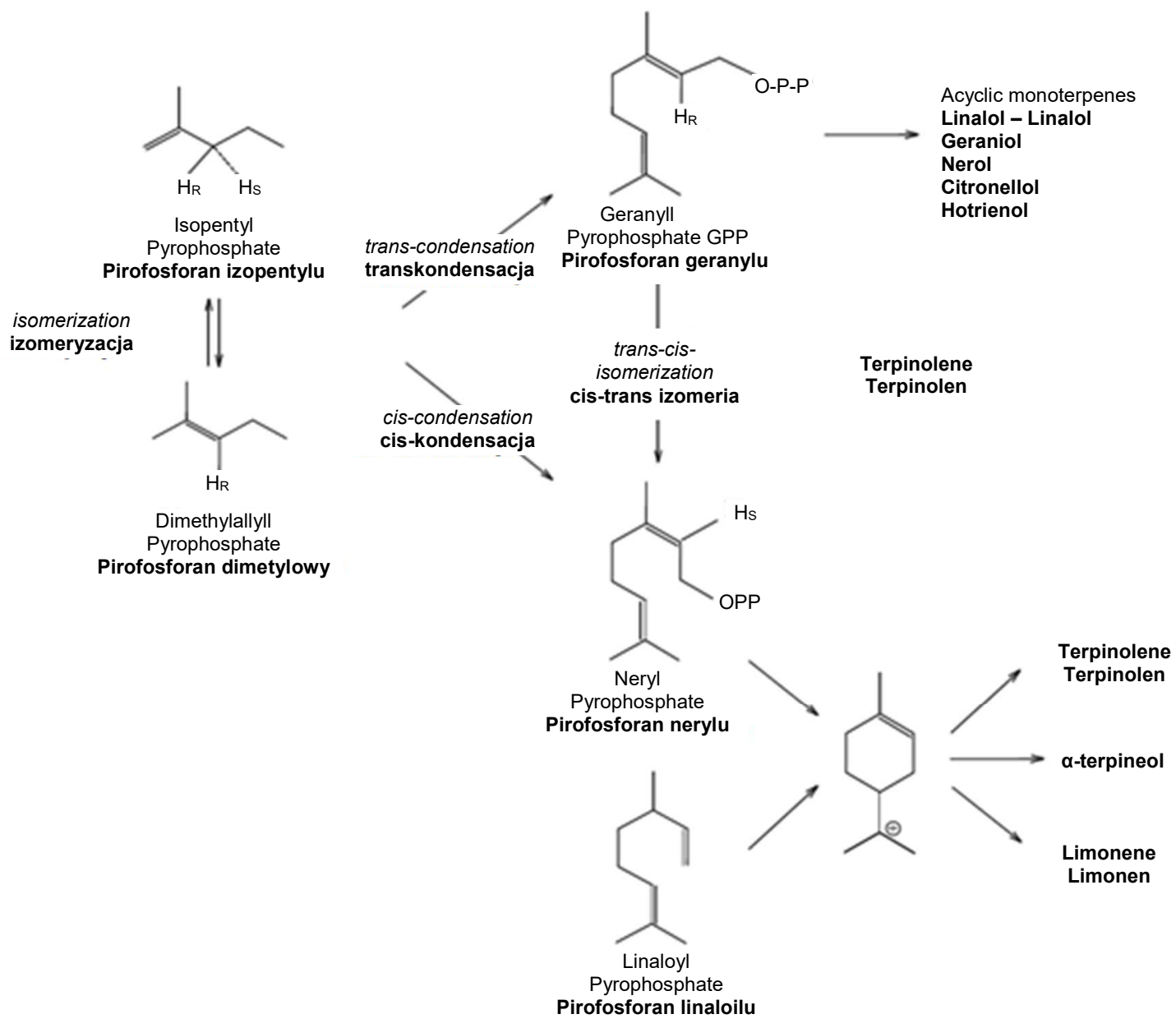

Fig. 2. Scheme of terpenes biosynthesis by Saccharomyces cerevisiae Ryc. 2. Schemat biosyntezy terpenów przez Saccharomyces cerevisiae 


\section{TERPENES AS THE AROMA COMPONENTS OF GRAPES AND WINES}

Qualitative and quantitative composition of volatile compounds in alcoholic beverages depends not only on the type and quality of raw materials and yeasts but also on conditions of fermentation, wine aging and storage of final products. Aroma compounds can give pleasant smell and taste or deteriorate sensory properties of wines. Volatile compounds are formed in biological, enzymatic and chemical processes(Pischl 2010). Table 1 present the selected, mean results of a few terpenes concentrations (GC-MS- Gas Chromatography-Mass Spectrometry) obtained after fermentation of red wines of Leon Millot, Rondo, Siegerrebe and Don Muscat varieties measuring in 7th, 14th, and 35th day of fermentation. The mean chemical data was separated using Duncan' multiple range test. Statistical analysis showed inconsistency of the obtained results. Concentration of terpenes changed over time significantly in most of the cases, but these changes were not gradual. Some of terpenes (e. g. $\alpha$-felandren, trans-geraniol, citral, ocimene) were found only in grape juices, while during fermentation, concentration of these components was diminished to the undetectable level. Terpenoids as highly volatile compounds. Danger for losing compounds is carried during storing of frozen samples in the fridge, storing the compounds in traps and heating the traps for short period of time before analysis. All these practices affect the final composition of terpenes and other volatile compounds (Zawadzka 2007).

Table 1. Effect of fermentation on mean chemical data of red wines obtained from fermentation of Leon Millot, Rondo, Siegerrebe and Don Muscat

Tabela 1. Wpływ fermentacji na średnie stężenie terpenów w winach czerwonych uzyskanych z fermentacji Leon Millot, Rondo, Siegerrebe i Don Muscat

\begin{tabular}{|c|c|c|c|c|}
\hline \multirow{2}{*}{$\begin{array}{c}\text { Terpenes } \\
\text { Terpeny } \\
\text { [mg/L] }\end{array}$} & \multicolumn{4}{|c|}{$\begin{array}{l}\text { Days of fermentation } \\
\text { Dzień fermentacji }\end{array}$} \\
\hline & 0 & 7 & 14 & 35 \\
\hline$\beta$-myrcene $-\beta$-mircen & $0.3806 a$ & $0.2420 \mathrm{a}$ & $0.2210 a$ & 0.1671 a \\
\hline Linalool - Linalol & $2.8585 \mathrm{c}$ & $3.6040 \mathrm{~b}$ & $3.8936 a b$ & $4.2301 \mathrm{a}$ \\
\hline Limonene - Limonen & $0.1957 \mathrm{~b}$ & $0.4360 a$ & $0.2888 a b$ & $0.1056 \mathrm{~b}$ \\
\hline
\end{tabular}

Values with different letters in rows are significantly different, $p \leq 0.05$, Duncan's multiple range test - Wartości o różnych literach w wierszach są znacznie zróżnicowane, $p \leq 0,05$, test Duncana.

Source - Źródło: based on - oparto na: Zawadzka (2007).

Table 1 shows that concentration of myrcene decreased during the fermentation while linalool increased. Level of limonene was slightly inconsistent but based on gradual changes from day 7 th to 35 th it can be assumed, that its concentration diminished. Amount of linalool was much bigger than its threshold value in wine 15-25 $\mu \mathrm{g} / \mathrm{L}$ (Guth 1997; Ferreira et al. 2000). Zawadzka (2007) showed there were clear differences between grape cultivars that influence the composition of wine at different stages of fermentation. Siegerrebe cultivar showed the biggest differences among the other studied cultivars. Its juice was very reach in terpenes ( $\alpha$-phellandrene, cis-linalool oxide, $\beta$-myrcene, trans-lialool, trans-geraniol, citral, ocimene), while in other analyzed juices dominated carbonyl compounds. In this study however terpenes 
present in Siegerrebe were not remained until the end of fermentation, but during fermentation other terpenes were formed (carvone, nerol oxide, limonene, linalool, hotrienol, trans rose oxide and citronellol) - Zawadzka (2007).

Monoterpenic alcohols such as linalool, geraniol, nerol, citronellol and $\alpha$-terpineol are the most important compounds in grape berries and are responsible for floral, fruity notes in the aromatic grape varieties of Muscat, Riesling, Viognier, Loureiro and Gewürztraminer (Arrhenius et al. 1996; Swiegers and Pretorius 2005; Luan et al. 2006; Oliveira et al. 2008). Other terpenes detect in grape and wines are presented in Table 2.

Table 2. Common and abundant terpenes at different grape and wines Tabela 2. Charakterystyczne terpeny występujące w różnych winogronach i winach

\begin{tabular}{|c|c|c|c|}
\hline $\begin{array}{l}\text { Terpenes in grape } \\
\text { Terpeny w winogronach }\end{array}$ & $\begin{array}{l}\text { Aroma quality } \\
\text { Aromat }\end{array}$ & $\begin{array}{l}\text { Terpenes in wines } \\
\text { Terpeny w winach }\end{array}$ & $\begin{array}{l}\text { Aroma quality } \\
\text { Aromat }\end{array}$ \\
\hline $\begin{array}{l}\text { Limonene } \\
\text { Limonen }\end{array}$ & $\begin{array}{l}\text { lemon, orange } \\
\text { cytrynowy, } \\
\text { pomarańczowy }\end{array}$ & $\begin{array}{l}\text { linalool } \\
\text { linalol }\end{array}$ & $\begin{array}{c}\text { floral, herbal, } \\
\text { lavender } \\
\text { kwiatowy, } \\
\text { herbaciany, } \\
\text { lawendowy }\end{array}$ \\
\hline $\begin{array}{l}\text { Eucalyptol } \\
\text { Eukaliptol }\end{array}$ & $\begin{array}{c}\text { mint, sweet } \\
\text { miętowy, słodki }\end{array}$ & geraniol & $\begin{array}{l}\text { rose, geranium } \\
\text { różany,geranium }\end{array}$ \\
\hline $\begin{array}{l}\text { Geraniol } \\
\text { Geraniol }\end{array}$ & $\begin{array}{l}\text { rose, geranium } \\
\text { różany, geranium }\end{array}$ & $\beta$-citronellol & $\begin{array}{c}\text { rose } \\
\text { różany }\end{array}$ \\
\hline Citronellol & rose & nerol & citrus, magnolia \\
\hline Citronellol & różany & & $\begin{array}{l}\text { cytrusowy, } \\
\text { magnolia }\end{array}$ \\
\hline$\beta$-bourbonene & $\begin{array}{l}\text { herbal } \\
\text { ziołowy }\end{array}$ & a-terpineol & $\begin{array}{c}\text { pine, lilac, citrus } \\
\text { sosna, lilia, } \\
\text { cytrusowy }\end{array}$ \\
\hline $\begin{array}{l}\text { a-guaiene } \\
\text { a-guaien }\end{array}$ & $\begin{array}{c}\text { wood, balsamic } \\
\text { drzewny, balsamiczny }\end{array}$ & $\begin{array}{c}\text { linalool } \\
\text { oxide } \\
\text { tlenek linalolu }\end{array}$ & $\begin{array}{c}\text { earthy, floral, herbal } \\
\text { ziemisty, kwiatowy, } \\
\text { ziołowy }\end{array}$ \\
\hline $\begin{array}{l}\text { a-humulene } \\
\text { a-humulen }\end{array}$ & $\begin{array}{c}\text { wood } \\
\text { drzewny }\end{array}$ & $\begin{array}{l}\alpha \text {-ylangene } \\
\alpha \text {-ylangen }\end{array}$ & pieprzny \\
\hline $\begin{array}{l}\text { a-muurolene } \\
\text { a-muurolen }\end{array}$ & $\begin{array}{c}\text { herbal, wood, spice } \\
\text { ziołowy, drzewny, ostry }\end{array}$ & $\begin{array}{l}\text { hotrienol } \\
\text { hotrienol }\end{array}$ & $\begin{array}{c}\text { tropical, floral } \\
\text { tropikalny, kwiatowy }\end{array}$ \\
\hline $\begin{array}{l}\text { Y-cadinene } \\
\text { Y-kadinen }\end{array}$ & $\begin{array}{c}\text { wood } \\
\text { drzewny }\end{array}$ & $\begin{array}{l}\text { rose oxide } \\
\text { tlenek różany }\end{array}$ & $\begin{array}{c}\text { geranium, green, } \\
\text { red rose } \\
\text { geranium, trawiasty, } \\
\text { czerwonej róży }\end{array}$ \\
\hline $\begin{array}{l}\delta \text {-cadinene } \\
\delta \text {-kadinen }\end{array}$ & $\begin{array}{c}\text { thyme, wood } \\
\text { tymiankowy, drzewny }\end{array}$ & $\begin{array}{c}\text { 4-vinylguaiacol } \\
\text { 4-winylogwajakol }\end{array}$ & $\begin{array}{c}\text { clove } \\
\text { goździkowy }\end{array}$ \\
\hline $\begin{array}{l}\text { cis/trans-calamenene } \\
\text { cis-trans kalamenen }\end{array}$ & $\begin{array}{l}\text { herbal, spice } \\
\text { ziołowy, ostry }\end{array}$ & $\begin{array}{l}\text { piperitone } \\
\text { piperiton }\end{array}$ & $\begin{array}{c}\text { mint } \\
\text { miętowy }\end{array}$ \\
\hline $\begin{array}{l}\alpha-\text { calacorene } \\
\alpha-k a l a c o r e n\end{array}$ & $\begin{array}{c}\text { wood } \\
\text { drzewny }\end{array}$ & $\begin{array}{l}\text { limonene } \\
\text { limonen }\end{array}$ & $\begin{array}{l}\text { lemon, orange } \\
\text { cytrusowy, } \\
\text { pomarańczowy }\end{array}$ \\
\hline $\begin{array}{l}\text { Cubenol } \\
\text { Kubenol }\end{array}$ & $\begin{array}{c}\text { spice, herbal, green tea } \\
\text { ostry, ziołowy, zielona } \\
\text { herbata }\end{array}$ & citral & $\begin{array}{c}\text { citrus } \\
\text { cytrusowy }\end{array}$ \\
\hline $\begin{array}{l}\text { Botrydial } \\
\text { Botrydial } \\
\end{array}$ & $\begin{array}{c}\text { green tea } \\
\text { zielona herbata }\end{array}$ & $\begin{array}{l}\text { rotundone } \\
\text { rotundon }\end{array}$ & $\begin{array}{l}\text { pepper } \\
\text { pieprzny }\end{array}$ \\
\hline $\begin{array}{l}\text { (E)- } \beta \text {-damascenone } \\
\text { (E)- } \beta \text {-damascenon }\end{array}$ & $\begin{array}{l}\text { apple, rose, honey } \\
\text { jabłkowy, różany, } \\
\text { miodowy }\end{array}$ & $\begin{array}{l}\beta \text {-ionone } \\
\beta \text {-ionon }\end{array}$ & $\begin{array}{l}\text { seaweed, flower } \\
\text { wodorosty, } \\
\text { kwiatowy }\end{array}$ \\
\hline
\end{tabular}

Source - Źródło: based on - oparte na: Michlmayr (2012); Vilanova et al. (2013); Wedler et al. (2015); Zhang et al. (2016). 
A sesquiterpene (rotundone) has been identified as the source of the peppery aroma of Shiraz wines (Rapp 1998; Wood et al. 2008). Types and proportion of terpenes change significantly during aging (Rapp and Günter 1986). The level of some increases and so their impact on sensory profile of wines as they are liberated from their glycosidic bondage, losses due to oxidation are also common. Most of monoterpene alcohols are converted to terpene oxides and these have sensory threshold approximately 10 times higher than their precursors and influence on aroma quality. An example may be the muscaty, iris-like aroma of linalool, that is progressively replaced by the musty, pine-like scent of $\alpha$-terpineol. During aging, additional changes can modify profile of terpenes in wine. Some of them are converted to lactones, such as 2-vinyl-2-methyltetrahydrofuran-5-one (from linalool oxides). Other terpenes can be transformed into ketons, for example $\alpha$-ionone and $\beta$-ionone. Monoterpene ketone piperitone, is associated with the mint shade detected in aged Bordeaux wine (Jackson 2016; Picard et al. 2016).

In order to determine the characteristic aroma of tested material, the best method would be gas chromatography with olfactometric port. The gas chromatography-olfactometry (GC-O) methodology couples traditional gas chromatographic analysis with sensory detection in order to identify volatile active compounds in complex mixtures. The human nose is an incredible detector for aroma components. As a result of such analysis, aromagram is obtained (Brattoli et al. 2014).

\section{CONCLUSIONS}

Terpenes occuring at very low concentrations are the most important aroma compounds in alcoholic beverages. Some of terpenes e.g. $\alpha$-felandren, trans-geraniol, citral, ocimene were found only in grape juice, while during fermentation concentration of these compounds were diminished to the undetectable level. The most common terpenes in wines are nerol, citronellol, geraniol, limonene, linalool, citral and $\beta$-ionone. Some of monoterpene alcohols are converted to terpene oxides; during agging some of them are converted to lactones, such as 2-vinyl-2-methyltetrahydrofuran-5-one (from linalool oxides); other terpenes can be transformed into ketons, for example $\alpha$-ionone and $\beta$-ionone. High nitrogen content above $400 \mathrm{mg} / \mathrm{L}$ stimulates monoterpenes biosynthesis, but does not affect on sesquiterpenes synthesis.

\section{REFERENCES}

Arrhenius S.P., McCloskey L.P., Sylvan M. 1996. Chemical markers for aroma of Victisvinifera var. Chardonnay region wines. J. Agric. Food Chem. 44, 1085-1090.

Brattoli M., Cisternino E., Gennaro G., Giungato P., Mazzone A., Palmisani J., Tutino M. 2014. Gas chromatography analysis with olfactometric detection (GC-O): an innovative approach for chemical characterization of odor active volatile organic compounds (VOCs) emitted from a consumer product. The Italian Assoc. Chem. Eng. 40, 121-126.

Carrau F.M., Medina K., Boido E., FarinaL., Gaggero C., Dellacasa E., Versini G., Henschke P.A. 2005. De novo synthesis of monoterpenes by Saccharomyces cerevisiae wine yeasts. FEMS Microbiol. Lett. 243, 107-115.

Clarke R.J., Bakker J. 2004. Wine flavour chemistry. Oxford, UK, Blackwell Publishing. 
Dixon J., Hewett E.W. 2000. Factors affecting apple aroma/ flavor volatile concentration. A review. N. Z. J. CropHortic. Sci. 28, 3, 155-173.

Drawert F., Barton H. 1978. Biosynthesis of flavor compounds by micro-organisms. 3. Production of monoterpenes by yeast Kluyveromyceslactis. J. Agric. Food Chem. 26, 765-767.

El Hadi M.A.M., Zhang F.J., Wu F.F., Zhou C.H., Tao J. 2013. Advances in fruit aroma volatile research. Molecules. 18. 8200-8229.

Fagan G.L., Kepner R.E., Webb A.D. 1981. Production of linalool, cis-nerolidol and trans-nerolidol, trans, trans-farnesol by Saccharomyces fermentati growing as a film on simulated wine. Vitis 20 , $36-42$.

Ferreira V., Lo'pez R., Cacho J.F. 2000. Quantitative determination of the odorants of young red wine from different grape varieties. J. Sci. Food Agric. 80, 1659-1667.

Fraternale D., Ricci D., Flamini G., Giomaro G. 2011. Volatiles profile of red apple from Marche Region (Italy). Rec. Natproducts 5(3), 202-207.

Gil M., Pontin M., Berli F., Bottini R., Piccoli P. 2012. Metabolism of terpenes in the response of grape (Vitisvinifera L.) leaf tissues to UV-B radiation. Phytochemistry 77, 89-98.

Guth H. 1997. Identification of character impact odorants of different white wine varieties. J. Agric. Food Chem. 45, 3022-3026.

Grassmann J. 2005. Terpenoids as plant antioxidants in vitamins and hormones. Plant Hormones 72 , 505-535.

Hayashi S. 1978. Natural compounds. Part 3. Steroids, terpenes and alkaloids. Eds. F. Korte, M. Goto. Stuttgard, Georg Thieme Publisher.

Jackson R.S. 2016. Wine tasting. A professional handbook. 2nd edition. Ontario, Canada, Elsevier.

King A., Dickinson J.R. 2000. Biotransformation of monoterpene alcohols by Saccharomyces cerevisiae, Torulosporadelbrueckii and Kluyveromyceslactis. Yeast 16, 499-506.

Klingenberg A., Sprecher E. 1985. Production of monoterpenes in liquid cultures by the yeast Ambrosiozymamonospora. Planta Med. 3, 264-265.

Luan F., Mosandl A., Gubesch M., Matthias M., WüST M. 2006. Enantioselective analysis of monoterpenes in different grape varieties during berry ripening using stir bar sorptive extraction- and solid phase extraction-enantioselective-multidimensional gas chromatography-mass spectrometry. J. Chromat., A 1112, 369-374.

Lund S.T., Bohlmann J. 2006. The molecular basis for wine grape quality. A volatile subject. Science 311, 804-805.

Martin D.M., Toub O., Chiang A., Lo B.C., Ohse S., Lund S.T., Bohlmann J. 2009. The bouquet of grapevine (Vitisvinifera L. cv. Cabernet Sauvignon) flowers arises from the biosynthesis of sesquiterpene volatiles in pollen grains. Proc. Nat. Acad. Sci. USA 106, 7245-7250.

Oliveira J.M., Oliveira P., Baumes R.L., Maia M.O. 2008. Volatile and glycosidically bound composition of Loureiro and Alvarinho wines. Food Sci. Technol. Int. 14(4), 341-353.

Picard M., Thibon C., Redon P., Darriet P., Revel G. de, Marchand S. 2016. Involvement of dimethyl sulfide and several polyfunctional thiols in the aromatic expression of the aging bouquet of red Bordeaux wines. J. Agric. Food Chem. 63(40), 8879-8889.

PischI J. 2010. Destylaty alkoholowe. Wytwarzanie, teoria i praktyka. Warszawa, Borus\&InterPolonus. [in Polish]

Rapp A., Güntert M. 1986. Changes in aroma substances during the storage of white wines in bottles, in: The shelf life of food beverages. Ed. G. Charalambous. Amsterdam, Elsevier, 141-167.

Rapp A. 1998. Volatile flavor of wine: correlation between instrumental analysis and sensory perception. Nahrung. 42, 351-363.

Reineccius G. 1998. Chemistry of essential oils. Flavor chemistry. Source Book of Flavors, Gaithersburg, Maryland, Springer, 74-88.

Swiegers J.H., Pretorius I.S. 2005. Yeast modulation of wine flavor. Adv. Appl. Microbiol. 57, 131-175. 
Wedler H.B., Pemberton R.P., Tantillo D.J. 2015. Carbocations and the complez flavour and bouquet of wine. Mechanistic aspects of terpene biosynthesis in wine grapes. Moluecules 20, 10781-10792.

Wood C., Siebert T.E., Parker M., Capone D.L., Elsey G.M., Pollnitz A.P., Eqqers M., Meier M., Vössing T., Widder S., Krammer G., Sefton M.A., Herderich M.J. 2008. From wine to pepper: rotundone, an obscure sesquiterpene is a potent spicy aroma compound. J. Agric. Food Chem. 28, 56.

Vilanova M., Genisheva Z., Grana M., Oliveira J.M. 2013. Determination of odorants in varietal wines from international grape cultivars (Vitisvinifera) grown in NW Spain. S. Afr. J. Enol. Vitic. 34, 2.

Zhang P., Fuentes S., Siebert T., Krstic M., Herderich M., Barlow E. W., Howell K. 2016. Comparison data of common and abundant terpenes at different grape development stages in Shiraz wine grapes. Data Brief. 8, 1127-1136.

Zawadzka N. 2007. Formation of volatile compounds in wines. MSc thesis. The Faculty of Life Science, Copenhagen University Department of Food Science (un published materials).

Abstract. Qualitative and quantitative composition of volatile compounds in alcoholic beverages depends mainly on the type and quality of raw materials and yeasts but also on conditions of fermentation, wine aging and storage of final products. Aroma compounds can give pleasant smell and taste or deteriorate organoleptic properties of wines. Volatile compounds are formed in biological, enzymatic and chemical processes as well as under thermal conditions throughout ethanol fermentation processes. Esters, aldehydes, higher alcohols, organic acids, and poorly examined - terpenes are the most important aroma compounds in alcoholic beverages. Some of terpenoids were found only in grape juice, while during fermentation concentration of these compounds were diminished to the undetectable level. The most common terpenes in wines are nerol (associated with citrus, magnolia aroma), citronellol (rose aroma), geraniol (with pleasant rose, geranium aroma), limonene (orange, citrus aroma), linalool (associated with floral, herbal, lavender), citral (with smell of citrus) and $\beta$-ionone (with pleasant seaweed, violet, flower, raspberry).

Research was financed by the Ministry of Science and Higher Education of the Republic of Poland. 